\title{
Discussion on the Contemporary Reflections on Enlightenment Rationality Paradox and Moral Education
}

\author{
Fengqin Chi \\ School of Maxism \\ Zhejiang University \\ Hangzhou, China 310028
}

\begin{abstract}
Moral education is based on the principle of confirming the value of human beings, which leads people to a true "adult" state. This is similar to the enlightenment rational thought represented by Kant and others. The principle of freedom and critical principles of enlightenment rationality lay the foundation for the development of subjective moral education. In the stage of "independence of human beings based on the dependence of things", the rapid development of modernity has led to the "rationality supremacy" phenomenon of "rational and worthless" and the paradox of enlightenment rationality. Marx and Habermas's critique of instrumental rationality and the reconstruction of enlightenment rationality have important implications for contemporary moral education, that is, the unity of practical rationality and communicative rationality.
\end{abstract}

Keywords-enlightenment rationality; paradox; instrumental rationality; moral education; the way to adult

\section{INTRODUCTION}

The development trend of enlightenment rationality has a very close internal relationship with the value orientation of moral education "way to adult". The full interpretation of the "human beings" value criterion and the conscious support of "self-ethical integrity" are the essence of the principle of enlightenment rationality in the moral education field. The rapid development of modernity gradually opens up the internal relationship between reason and value, and triggers the paradox of enlightenment rationality. The reconstruction of enlightenment rationality is of great significance to the return of moral education "way to adult".

\section{THE START OF RATIONAL FREEDOM, HUMAN AWAKENING AND MORAL EDUCATION "WAY TO ADULT"}

The use of enlightenment rationality returns the essential power of human beings to human beings, and the principle of freedom of its connotation lays the foundation for the development of subjective moral education. First of all, the awakening of subject consciousness or the criterion of one's own thinking as a positive freedom, established the moral principle of "people legislate for themselves". Kant pointed out in "What Is Confirming the Direction in Thinking": "Own thinking is called the supreme touchstone of finding truth in itself (that is, in its own rationality); and the principle of thinking at all times is enlightenment." [1] This involves two dimensions: first is to know yourself. This promotes moral education to be based on respecting the law of individual growth and development, which gives individuals the choice of moral principles, and the independent judgment of moral situations as the core individualized process realizing the creative transformation from external infusion to introspection. Second is becoming yourself. For the meaning construction of moral education, the moral selfconfidence and free and conscious moral activities of the individual are the most basic guarantee. Secondly, getting rid of the juvenile state as a negative freedom, points out the congenital abduction of the passive and spontaneous state of human development, such as childishness, laziness, fear, dependence, etc., and establishes the basic bottom line for the development of moral education, that is, changes the traditional "collectivization" face, liberating people from the obscurant state dominated by the guardian. Thirdly, the rational freedom of public use as a kind of freedom of practice is the use and promotion of the positive freedom of "self-thinking" and the negative freedom of "getting out of the juvenile status." The mission of moral education is not the unpredictable abstract ideals away from human reality stipulation. "Using the rational freedom of the public in all matters" provides an intrinsic motivation for moral education to transcend the rational centralism of the metaphysical level and integrate into the field of individual life. The importance of public use of rationality over private use "implies the universal attributes of every rational person as a participant in the practice of communicative life or a participant in public moral life". [2] This provides a possibility for the realization of the goal of moral education "to become yourself and then become a human-being" and the delicate balance between moral freedom and moral responsibility.

The critical spirit of enlightenment rationality provides the impetus for the emergence of reflective moral education. The application of the principle of liberty is undoubtedly the "golden key" for moral education to open the "way to adult". However, how to grasp the "way to adult" in the complicated real world and guarantee the rationality of the principle of freedom is related to the most important thing in the 
development of moral education. As a companion to the spirit of freedom, the critical spirit only makes up for the shortcomings of moral nihilism in moral education caused by excessive emphasis on individual freedom. Leaving the critical spirit and talking about freedom is likely to cause the break of the enlightenment rationality connotation, and it is impossible to restore its true essence. Kant and Foucault have a high degree of consistency in the critical aspect of the enlightenment rationality connotation, and both regard the critical spirit as the modern temperament and attitude of enlightenment. Kant stressed: "It is very difficult to maintain or establish such a purely negative thing in the way of thinking (especially in the public way of thinking) (it constitutes a true enlightenment)." [3] Foucault pointed out: "Enlightenment is to permanently activate an attitude, that is, to activate the temperament of philosophy. This temperament is characterized by a permanent critique of our historical existence." [4] Specifically, enlightenment rationality promotes the development of reflective moral education from both external criticism and internal criticism. On the one hand, from the perspective of external criticism, ethical subjects with enlightenment consciousness in the specific moral scene and moral situation in the principle of different from time to time, by criticizing the singular ethics, breaks the superstition of moral authority and achieves a rational resistance to the unchanging moral authority, which controls the constraints of normative ethics on people's behavior within a reasonable limit, and then pushes the reform of moral education under the guidance of normative generalization, emancipating people from the intertwined state of "inaction" and "indulgence" of the state of ignorance of the moral world and the state of "acceptance" and "obedience" of hindsight, and always maintaining a state of "reflection" and "thinking" about moral events, moral behaviors, moral concepts, and moral attitudes to alleviate the numbness and contempt of existence. In this sense, it can be said that the critical spirit is a self-prepared weapon that has a moral personality with independent personality to avoid falling into a rabble. On the other hand, from the perspective of internal criticism, enlightenment must be understood as a form of criticism of the reflexive inner finger, which gives the moral subject a basic internal drive to reflect on its own moral behavior and consistent values. Nietzsche creatively proposed the spiritual declaration of "God is dead." "Things to you are what they present to you, and to me are what they present to me" [5]. The image illustrates the diversified development of individual moral values. However, casual ethical freedom as the subjective appeal of the self has become an important theoretical rhetoric of moral education diversification. The moral subject responds to the self-interested morality of the "self" with the combined effect of "self" and "super-ego".

\section{INSTRUMENTAL RATIONALITY, HUMAN ALIENATION AND THE DEVIATION OF MORAL EDUCATION "WAY TO ADULT"}

In the stage of "independence of people based on the dependence of things", rationality replaces religious mythology as the new "authority" of all things, which makes the enlightenment rationality aimed at breaking the ideology control of religious authority on human beings as a universal standard for measuring everything, shaping a new form of control, and appearing self-disintegration, or the paradox of enlightenment rationality becomes inevitable. This leads to the fact that the instrumental rationality with precise calculation and utilitarian infinity calculation as the secularized version of enlightenment rationality becomes the ideological weapon for capitalism to realize rationality. However, despite the forging of a developed industrial society, such changes have also distorted the fundamental prescriptive nature of human beings, degrading people into instrumental existence subject to foreign objects, which fundamentally limits the ethical care of mutual assistance, warmth and friendship between people in public life. Individuals under the control of instrumental rationality are increasingly developing towards utilitarianism, and in the meantime, they continue to conduct virtue transactions, value-dissolving activities, and tend to be exquisite selfinterests. The moral education under the circumstance of instrumental rationality is in the dilemma of "de-moralization or im-moralization", which is completely contrary to the "way to adult" under the guidance of enlightenment rationality.

The preference of instrumental rationality for knowledge leads to the separation of moral knowledge education and life moral education. Enlightenment rationality appeals to "disenchantment" and derogatory illusion raises narrowly objective knowledge to an unprecedented decisive position. "Knowledge is power" becomes the golden rule that governs the entire education system (including moral education). Moral education stemming from life and belonging to life is being replaced by a knowledge-based moral education curriculum. As a result, moral knowledge education and intellectual education are similar in terms of development process, operation mode, functional system and assessment methods, and are gradually losing the unique meaning of "way to adult". "Although scientific moral education can make students master a large amount of moral knowledge... moral education may still be ineffective... and it may have the opposite effect and negative influence... it may cause the distorted personality of the educated person." [6] When moral knowledge education uses the rationality of instrumental rationality to erase the diversity of individual moral needs, the individuals it creates are only blind believers of countless reproducible moral knowledge.

The "technique only theory" and "capital only theory" of instrumental rationality triggered the crisis of meaning of moral education. In modern times, Descartes established the principle of digital rationality based on the interpretation of mathematics. "For the Enlightenment, what cannot be reduced to digital, or eventually cannot be restored to too one, is an illusion." [7] Instrumental rationality "technique only theory" is like the flood and beasts, sweeping people in all areas of production and life, which turns people with a sense of autonomy into things that are governed by the logic of capital. This makes the social development show a phenomenon of antinomy: the more obvious the diversification of science and technology and the tendency of civilization, the more serious the simplification and 
materialization of human beings. The developed industrial civilization infinitely magnifies the selfish and profit-seeking "economic man" nature. Affected by this, the ecosystem of moral education is facing three major imbalances between human-beings and nature, between people and between people and self. First of all, instrumental rationality takes human conquest and control of nature as a symbolic manifestation of the role of science and technology, which makes the equality and responsibility relationship between man and nature degenerate into the relationship or purpose between master and slave in the perspective of instrumental rationality - end means relationship. Undoubtedly, the development of science and technology offers many possibilities for people to enrich their living resources and improve their living standards by means of natural forces. However, the exploitation of natural resources and the random trampling of the natural environment have made people's sense of morality and responsibility for nature disappear. Secondly, instrumental rationality exerts the competition, comparison and indifference between people to the fullest, leading to the decline of the moral community spirit. Faced with the collusive features of modern social technology and capital and the prevalence of quantitative value, the qualitative value of the matter itself is questioned and even despised. The self can only determine the position and confirm the value in the comparison, and can exclude the dissident and realize the value in the competition. Although there is no obvious "war" relationship between people in the Hobbes context, it presents a more invisible and more difficult to defend confrontation relationship. Thirdly, instrumental rationality regards the self-holding of the subject as the ultimate goal of the theory of technology and capitalism. The abstract and fragmented moral subject dissolves the physical existence of human beings, leading to the excessive expansion of subjective moral education.

\section{THE RECONSTRUCTION OF ENLIGHTENMENT AND THE RETURN OF MORAL EDUCATION "WAY TO ADULT"}

Horkheimer and Adorno fully analyzed the pathology of instrumental rationality, and overall they were pessimistic about instrumental rationality, so they made the conclusion that the tool rationality was used to save the modernity crisis. However, they adopted a total negative attitude towards enlightenment rationality, and criticized the instrumental rationality together with the true value of enlightenment rationality. Marx is based on the historical materialism and explores the existence of enlightenment rationality in the field of material life. Marx's assertion of "the inevitable demise of capitalism and the inevitable victory of socialism" and the conception of the future society expounds the revolutionary concept of the existing world from the perspective of practical rationality, and explores a new path for the transformation of enlightenment rationality. Habermas affirmed Horkheimer and Adorno's critical attitude towards instrumental rationality. However, it is not limited to this. It adopts a philosophical stand that breaks and stands, focusing on the reconstruction of enlightenment rationality from the intersubjective, spiritual, and ethical dimensions. This greatly complements and perfects Marx's critical reconstruction of enlightenment rationality, and opens up a new horizon for the mutual understanding and trust of moral subjects in risk society. However, Habermas's neglect of the value of labor and material communication has reverted the enlightenment rationality in practice to a paradigm of consciousness or a paradigm of spirit. Therefore, the way to adult of contemporary moral education should adhere to the unity of communicative rationality and practical rationality.

In order to break the rigid and closed internal structure of identity metaphysics, Habermas is committed to the path of transformation from subjectivity to intersubjectivity. In his view, reasonable and effective communication behavior relies on a rich and specific discourse system, which has basic requirements such as the authenticity of opinions, the sincerity of communication, the comprehensibility of both parties, and the justification of conformity. "Every subject with linguistic and behavioral ability, consciously giving up power and violent use, can participate freely and equally in the argumentation of discourse, and in this process, everyone must be motivated and willing to pursue truth and obey the truth." [8] This is an important reference for moral subjects who hold different values to reach a universal moral consensus. Compared with the traditional acquaintance society characterized by the stability and persistence of communication, the stranger society has the virtual and fluid characteristics of communication. In the information society where the tools of communication are increasingly diverse and the opportunities for communication are becoming more frequent. The moral education of "having communication and irrationality" is particularly obvious. This understanding of communicative rationality undoubtedly raises new problems. Therefore, more accurately clarifying the core of Habermas's communicative rationality will become an important prerequisite for reconstructing the moral education of way to adult. On the one hand, moral education in the path of communicative rationality changes the traditional monologue moral education, and advocates a kind of dialogue-based moral education to correct the wrong tendency of the philosophical paradigm of consciousness that is represented by "ego cogito ergo sum" in recent years. From the perspective of the internal relationship between communication and reason, rationality has the value shaping and normative constraints on communication. The embedding of communicative rationality realizes the inner integration of moral education field interaction and rationality, promotes the organic transformation of the instrumentality to value of communication, and restores the "way to adult" that is distorted by instrumental rationality. On the other hand, moral education in the path of communicative rationality is aimed at the moral education crisis with strong knowledge and weak value, and has repositioned moral education. In Habermas's view, the language communication structure between the speaker and the listener takes people as the expressers of self-will. Its establishment provides a place for people to express moral feelings and demonstrate moral will.

Marx's moral concept is directly generated from the realistic view of the human existence, the thorough critique of the capitalist system, and the deep concern for human 
liberation. In his view, moral education is not an abstract regulation of transcendental humanity style, but through the revealing and analysis of the alienation state of capitalist social people, inspiring people's intrinsic motivation to use practical rationality to overcome transcendental rationality and instrumental rationality. If the transcendental rationality is expressed as the blind worship of the metaphysical rationality of the individual from accepting the test of social practice, the instrumental rationality manifests itself as the blind obedience of the materialized rationality derived by the inner impulse, then practical rationality hides the rational norms that individuals control their own impulses and make them consistent with the essential power of human beings. In Marx's view, rationality is rationality contained in the field of practice, and practice is the practice under the guidance of enlightenment. Marx spans the gap between practice and reason, and proves the intrinsic connection between "human beings are living reality" and "human beings are a free and conscious existence" as different expressions of human nature. The importance of human nature to human development determines the importance of practical reason to moral education. Specifically, on the one hand, moral individuals under the guidance of practical rationality recognize the urgency and importance of using critical weapons to defend moral integrity, correct moral deviation, and change the existing state of existence suppressed by capital and power. Marx said: "After the sacred image of human self-alienation is exposed, exposing the alienation of self with a non-sacred image becomes an urgent task of philosophy that serves history. Thus, the critique of the kingdom of heaven became a critique of the earth, the critique of religion became a critique of the law, and the critique of theology became a critique of politics." [9] People always experience the phenomenon of "non-human" alienation in the process of being a human-being and becoming a human-being. Marx is committed to the integration of practical reason into the moral life of the people in the form of stripping into the essence of life. On the other hand, practical rationality in the response to the question of how morality and virtue are consistent, showing the superiority of communication rationality beyond Habermas's stay in spiritual communication. The moral individual under the guidance of practical rationality upholds the position of unity of knowledge and action, and resolves the moral paradox of "knowing virtue and not doing morality" in moral practice. In a nutshell, the exercise of the function of rationality makes moral education in an excellent state of rationality, rationality, and unity of value and rationality. This kind of excellent state is the basic premise of the return of the "way to adult".

\section{CONCLUSION}

From the small-scale development of any civilization in history to the leaping development of the times, it is based on the development of people's moral freedom consciousness. The principle of freedom of enlightenment rationality lays the foundation for the development of subjective moral education. The critical spirit of enlightenment rationality provides the impetus for the emergence of reflective moral education. However, instrumental rationality leads to the deviation of human alienation from the "way to adult" of moral education. The reconstruction of enlightenment rationality lays the foundation for moral education to overcome the alienation phenomenon brought by instrumental rationality and realize the return of human beings. Marx is based on the historical materialism and explores the existence of enlightenment rationality in the field of material life. Habermas focuses on the reconstruction of enlightenment rationality from the intersubjective, spiritual, and ethical dimensions. Therefore, the way to adult of contemporary moral education should adhere to the unity of communicative rationality and practical rationality.

\section{REFERENCES}

[1] Li Qiuling, Complete Works of Kant's Works, Volume 8. Papers After 1781 [M] Beijing: China Renmin University Press, 2013: 142. (in Chinese)

[2] Liu Jing, Why do We Have the Obligation to Each Other? - The Sources of Normativity of Stranger Society and Contemporary Construction [J] Journal of Northeast Normal University (Philosophy and Social Sciences), 2019 (4). (in Chinese)

[3] Li Qiuling, Complete Works of Kant's Works, Volume 5, Kritik der praktischen Vernunft, Kritik der Urteilskraft [M] Beijing: China Renmin University Press, 2013: 306 - 307. (in Chinese)

[4] (France) Foucault, Du Xiaozhen ed. Collection of Foucault [M] Shanghai: Shanghai Far East Publishers, 2003: 528. (in Chinese)

[5] Luo Guojie, Song Xiren, History of Western Ethics Thoughts (Vol. 1) [M] Beijing: China Renmin University Press, 1985: 88. (in Chinese)

[6] Tang Hanwei, Life Moral Education Theory [M] Beijing: Educationa Science Publishing House, 2005: 13. (in Chinese)

[7] (German) Horkheimer, Adorno, Enlightenment Dialectics Philosophy Fragment [M] Qu Jingdong, Cao Weidong, trans. Shanghai: Shanghai People's Publishing House, 2006: 5. (in Chinese)

[8] Zhang Guofeng, Interview with Habermas [J] Foreign Literature Review, 2000 (1). (in Chinese)

[9] Selected Works of Marx and Engels (Vol. 1) [M] Beijing: People's Publishing House, 2012: 2. (in Chinese) 